\title{
The implementation of freedom of speech principles in Indonesian press regulation
}

\author{
Putri Tunjung Sari a, ${ }^{a, 1}$, \\ airlangga University, Airlangga St. No. 4-6, Surabaya 60115, Indonesia \\ ${ }^{1}$ putritunjung14@gmail.com* \\ * corresponding author
}

\section{ARTICLE INFO}

Article history

Received 2020-04-21

Revised 2020-04-26

Accepted 2020-06-03

Keywords

Press Regulation

Press

Freedom of speech

Regulation

Media Communication

\section{ABSTRACT}

This paper aims to see the implementation of freedom of speech principles in Indonesian press regulation, because as we have known, this regulation was made in very short period during political change in Indonesia. This change influences the Press Law too. The change in the Press Law which has further facilitated freedom of speech, it turns out to have a big impact on numerous parties, especially journalists and owners of mass media business entities. In this study, the researcher used critical paradigm to see effect of this law and problems those might be came because of the implementation. This study found that the implementation, freedom of speech regulated in the 1999 Press Law often turns out to intersect with the freedom of others so that it needs to be evaluated, reviewed, and revised.

This is an open access article under the CC-BY-SA license.

\section{Introduction}

The 1999 Press Law is a regulation that forms the basis of press practice in Indonesia and makes the Journalistic Code of Ethics a reference for journalists in Indonesia. The researcher interested in analyzing the 1999 Press Law in its implementation in mass media since the researcher found several cases of alleged defamation by the person who is the object of reporting done by journalists, for instance, Bambang Harimurti and Tomy Winata in the case of profiteering Tomy Winata in reporting "Ada Tomy in Tenabang" or "There is Tomy in Tenabang" in the Tempo print media [1].

Based on Tempo online [2], it was known that this case stemmed from the news from the mass media, Tempo, about the alleged connection of Tomy Winata in the case of the Tanah Abang Market burning. Tommy Winata was the owner of the Artha Graha Group, while Bambang Harimurti was the Editor in Chief of Tempo Magazine at the time. Bambang Harimurti was responsible for the writing done by a Tempo journalist who reviewed the possibility of Tomy Winata being involved in the case of the Tanah Abang Market burning. The Tempo reporter was considered to have written the news without prior confirmation to Artha Graha and only used anonymous sources. It was stated that the anonymous source was an architectural consultant used by Tomy Winata in making development planning for the Tanah Abang Market, to be submitted to the Jakarta Regional Government. According to Tomy, the news in the mass media has harmed himself individually and the company as a whole, because he felt his reputation and the company became polluted and his employees experienced threats from people who on behalf of themselves as residents of Tanah Abang. 
The case of Tomy Winata and Bambang Harimurti cannot be resolved with the settlement of civil or criminal law in the District Court, because problems in the press can only be resolved by the 1999 Press Law through the Press Council. This was felt to be unfair to Tommy Winata since this problem was resolved with the right of reply accommodated in Tempo's printed media. The material and immaterial losses that have been experienced due to the circulation of the news cannot be replaced through the right of reply.

The case of Tomy Winata and Bambang Harimurti is compelling for the researcher because the researcher sees the impact and inequality that occurs with the implementation of the 1999 Press Law. On one side, the 'freedom' is granted through the 1999 Press Law to Indonesian press personnel, on the other side, this can be considered detrimental to other communities.

Actually case of Tanah Abang is not the only problem that occurred because of the blurry barrier of freedom of speech as in 1999 Press Law, and not only in printed media this can be happened. In this era, which internet as our first reference in searching information, we can find similar cases too. As an example, Merdeka online [3] site publish a news about unrest tragedy in Makassar Public University (Universitas Negeri Makassar or UNM) which in this tragedy had two dead victims. The fight happened between Language and Art Faculty because two of them accidentally bumped their motor cycle. Because of this news, Adinuansa started a petition to Press Council because he found that some information in this news and the picture were not correct and it against Journalistic Code of Ethics [4].

These problem does not stop there, even in this era, that can still happen. These days we hear a lot of information about Corona Virus or Covid-19 issue, when the President finally announced that they found two cases of Corona Virus, the press looked for deeper information until they found out about patient's personal data and published it. This made the patients felt uncomfortable because of public's stigma [5]. Beside that, sometimes journalists post irrelevant and inappropriate pictures to describe the situation, for example in Kuningan Bomb tragedy which some journalists posted uncensored picture of the victims and using over generated words [6], and this could make the victim's families hurt and people who read or watch the news feel uncomfortable too.

By looking at these cases, the researcher interested in analyzing the press regulation, the basis of regulation, and sees the implementation of freedom of speech in other countries as evaluation and suggestion to review and revise the existing press regulations to be better.

\section{Theorical Framework}

\subsection{Press Freedom Regulation in the 1999 Press Law}

Historically, press regulation began from Persbreidel-ordonantie, the 1966 Press Law, the 1967 Press Law, 1982 Press Law, and the last was the 1999 Press Law and the Press Code of Ethics. This 1999 Press Law repealed the previous Press Law, following Article 20 of the Final Provisions.

As Press Council [7] the 1999 Press Law was made during the fall of the new order and replaced existing laws that gave the president authority to control the press system on the grounds of maintaining national stability. Whereas the Press Law No. 401999 gives more control authority to the public, especially the Indonesian Press, for example in Article 15 paragraph [8] (1) which states that, "In an effort to develop the freedom of the press and expand the existence of the national press, a Board of the Press is established." The Board of the Press has the following functions; (1) protect the freedom of the press from any intervention; (2) conduct studies to develop the existence of the press; (3) decide and control the compliance of Code of Ethics of Journalistic; (4) give consideration and find solutions any complaint lodged by public towards cases concerned with press' reportage; (5) develop communication between press, public and government; (6) facilitate press' organizations in order to form regulations in press as well as increase the quality of journalistic professionalism; (7) register press companies [9].

In addition to the aforementioned article, the researcher also finds several other articles that supported the values of press freedom. In Article 1 as in [8], it is explained that any party is prohibited from carrying out activities of forced removal or cencorship of information material to be broadcast or published. This includes the prohibition of committing warming or intimidation. The activities to stop the publication and distribution or broadcasting by force are included in unlawful 
banning. This shows that the press has freedom and discretion in carrying out journalistic activities because banning and censorship are not permitted which are considered to restrict journalists' freedom in presenting ideas and information.

Based on the aforementioned law, the Press Council can be identified as an independent body that is not influenced by any power and has the main function in establishing the Journalistic Code of Ethics as a reference for journalists' work, as well as conducting supervision in its implementation.

This Journalistic Code of Ethics is produced by, from, and for journalists, so that it is personal or means that it depends entirely on the journalist's conscience. This Journalistic Code of Ethics is also discussed in Article 7 paragraph (2) as in [1], namely "Journalist owns and adheres to The Ethic Codes of Journalistic." There are eleven articles in the Journalistic Code of Ethics , namely: (1) The Indonesian journalist is independent and produces news stories that are accurate, balanced and without malice; (2) The Indonesian journalist adheres to professional methods in the execution of a journalistic duties; (3) The Indonesian journalist always verifies information, conducts balanced reporting, does not mix facts with biased opinion, and upholds the presumption of innocence principle; (4) The Indonesian journalist refrains from producing false, slanderous, sadistic and obscene news stories; (5) The Indonesian journalist does not disclose and broadcast the identity of victims of a sexually-exploitative crime and refrains from identifying a minor who committed a criminal act; (6) The Indonesian journalist does not misuse his/her profession and accepts no bribe; (7) The Indonesian journalist has the right of refusal to protect the identity of a news source who does not wish his/her identity and whereabouts known, and abides by the conditions for an embargo, background information and off the record as mutually agreed; (8) The Indonesian journalist does not write or report news based on prejudice or discrimination against anyone on the basis of differences in ethnicity, race, color, religion, gender, and language and does not degrade the dignity of the weak, the poor, the sick, the mentally or physically handicapped; (9) The Indonesian journalist respects the right of the news source's private life except in the public interest; (10) The Indonesian journalist immediately retracts, rectifies, and corrects errors and inaccuracies in a news story accompanied with an apology to readers, listeners or viewers; (11) The Indonesian journalist accedes to the right of reply and the right of correction in a proportional manner [10].

In the implementation of this code of conduct, it is not uncommon for a violation to occur towards the Press Law and Journalistic Code of Ethics which cannot be resolved through litigation, this is because it is Lex Specialist or extraordinary and has certain procedures. Therefore, problems related to press violations must be solved first to the Press Council to obtain mediation and agreement. According to Hikmat [10], this extraordinary problem-solving is a consequence of the Journalistic Code of Ethics was made by journalists and supervised by journalists who are members of the Press Council. However, when the press problems cannot be resolved through the Press Council, the cases can be agreed to be resolved through police [11].

This Journalistic Code of Ethics is universal which binds journalists in a country or another. This is because the Journalistic Code of Ethics has the same essence and is applied throughout the world. The essence of the Journalistic Code of Ethics is; their balance in their news, neutral, objective, accurate, factual, do not mix up the facts and opinions, do not insert personal matter (privacy), respecting the presumption of innocence, not defamatory, false and obscene, and the title reflects the content news [10].

\subsection{Freedom of Speech Principles}

Freedom of speech in the world of journalism means freedom to seek, obtain, and disseminate ideas and information. This freedom of speech is guaranteed by the 1999 Press Law in Article 4 [8], as the citizen's human rights guaranteed by the state. Citizens' human rights are regulated in Article $28 \mathrm{~F}$ of the 1945 Constitution [12], "Every person shall have the right to communicate and to obtain information for the purpose of the development of his/her self and social environment, and shall have the right to seek, obtain, possess, store, process and convey information by employing all available types of channels." Thus it can be seen that the freedom of the press in conveying information by using all available channels and communicate is journalists' right to fulfill society's needs for information. There is a mutual need relationship between journalists and nonpress communities. Robert G. Pickard and Victor Pickard [13] state that, aside from the law, freedom of speech is also protected in Article 19 of the Declaration of Human Rights. 
The freedom of speech principle is the basic principles of communication regulation. Napoli [14] explains that there is a regulation aimed at one principle and can relate to other principles. "It is important to recognize that the policies directed at one of these foundation principles can have effects pertaining to the other principles." The principles are: (a) the first amendment; (b) the public interest; (c) the marketplace of media; (d) diversity; (e) competition; (f) universal service; $(\mathrm{g})$ localism. This freedom of speech discussion is included in the principle of the first amendment. "The first amendment states simply that congress shall make no law abridging freedom of speech or of the process." [14]

The first amendment is positioned as a structure because it has a relationship with each principle. There are several functions of the first amendment, one of them is the liberty or selffulfillment function. Freedom of speech is important for self-fulfillment and it is important for individuals to feel integrity and be valuable [14].

According to Barker in Napoli [14], the main value about freedom of speech is the freedom of self to define, build, and express themselves and affect the speaker. For example in the case of Vietnamese war protesters who promoted the slogan 'Stop this War Now' during the demonstration. He could have done this without hope, for example its influence on whether the war would continue or whether the leaders in power heard it. It could be that these protesters shout and participate so they are defined as opponents of the war. Out of protests about this war can emerge dramatic illustrations of the urgency of expensive speech, apart from any effective communication with others."[14]

The first amendment principle on freedom of speech is criticized for failing to distinguish speech from other forms of human activity so that it fails to explain how speech gets a unique portion and protection under the constitution and how the first amendment protects forms of speech expression more than non-speech. This freedom of speech cannot explain the scope of action from free speech to self-freedom and self-fulfillment, so the rationalists suggest specific selfexpression to show one's point of view in the form of actions and behavior to get the same protection as speaking [14]. This freedom of speech, besides benefiting oneself in conveying ideas, opinions, and debate relating to personal and public matters, Garton said in Robert G. Pickard and Victor Pickard [13], was also seen as beneficial for the social environment. Thus, it is necessary to make media and communication regulations that accommodate freedom of opinion for the public and private.

Regulations relating to public expressions in print or broadcast media and the internet must be improved in terms of giving and receiving information, ideas and participation in debates. Policy makers must pay more attention to freedom of expression and communication in the public sphere, and not to limit and judge based on social care. As Fisher and Harms [13] once stated that the effective right of individuals to accept ideas, opinions and information, and to disseminate their view is as important as the obligation not to interfere with these expressions. Raboy and Shtern [13] reinforce this statement by stating that the right to expression and communication are basic rights in democracy [13].

Besides the concept of freedom of speech, included in freedom of expression is freedom of the press, the right to answer, fair access to communication, the right to know information, and different opinions. Freedom of expression is a basic right that is not unlimited. The limit of freedom of expression is regulation. As Robert G. Pickard and Victor Pickard [13] regulations should be made to preserve freedom without neglecting national defense, protecting the public interests as well as the interests and dignity of individuals. So, policymakers must examine the regulations made whether it is appropriate. "When addressing such issues, policymakers in democratic states need to exercise great care to ensure that any constraint on the right to free expression is specific, justified, reasonable, and would satisfy and independent judicial body." [13]

Therefore, it can be concluded that the making of regulations must consider various parties and aspects, not only concerning the interests of one of the parties, such as regulations governing freedom of expression and communication from journalists contained in the 1999 Press Law may not rule out the interests of other communities not included in press unions, although freedom of expression and communication are journalists' rights who are also part of citizens and part of efforts to fulfill the need of information for the wider community. Freedom of expression and communication must not damage individual interests, because the interests of other individuals are 
also protected by the state. Moreover, this freedom must still consider the aspects of national security and stability.

\subsection{Press Regulation Implementations Related to Freedom of Speech in Other Countrie}

Regulations in a country are inseparable from the political system adopted by the country, for example in Indonesia itself. Bagir Manan [15] explained that Indonesian political system, democracy, is related to press. Press is the fourth element after three elements in Trias Politica by Montesquieu. In Trias Politica, those elements are legislative, judicative, and executive. Press is one of democratic characteristics beside rule of the law and alternative and freedom of choosing among the alternatives. Media is also an indicator of political openness because media gives stimulus in political openness by giving information that actual and critical which can make people realize the importance of political system [16]. If press has important meaning in democracy political system, it is different to communist political system. Ratna Dewi [17] tried to explained the importance of mass media in both political system, with using United States (US) and Russia as the examples. In US, mass media has similar function as Indonesia, but in Russia, mass media has function as a propaganda media. Because of this difference, the researcher wants to see differences the implementation of freedom of speech in press regulations in China and Norway since both countries have a far different political system.

\section{1) Freedom of the Press in China}

China was ranked 177 in 2019 on the online site [18], an online site that ranks press freedom in delivering information (reporters without borders for freedom of information). China's ranking is the lowest of 180 countries. So, it can be seen that the implementation of freedom of speech in China is not going well.

The Chinese Constitution has guaranteed freedom of speech, but in reality, this freedom cannot be applied in the lives of the Chinese people. This is due to freedom of expression or speech only applies to political elites. "The only people in China who can publish criticism of, or opinions contrary to those of, the communist party, are senior members of the Communist Party." While elite intellectuals and professionals get the opportunity better when compared to ordinary people to question the political policies in public, criticize in private and restricted forum [19].

China adheres to the Socialist-Communist Political system. According to Tohir Bawazir [20], Social-Communism is an understanding that all assets are the property of the state and are used for the overall prosperity of the people. Since the focus of this communist understanding is the management of all things by the government, the government has enormous authority, including in intellectual properties, opinions, ideas, and thoughts considered by the state to disrupt the stability and prosperity of the people. As Ellen R. Eliasoph [21] this is proven by the disarmament of the writer and editor, Wei Jinsheng, because his writings relating to differences in political views. Also, the Central Committee of the Communist Party filed for the revocation of "Four Big Right", where the right regulates freedom of expression, freedom of speech, holding large debates, and writing on posters.

The Chinese government strictly regulates what can be said and done by its citizens in expressing themselves even though the Chinese Government has declared to guarantee freedom of expression. This reality of pseudo freedom makes people who work in journalism and arts like; filmmakers and websites or content creators experience fear because if the message in their writing or work cannot be accepted by the government, they will get punishment. These can include harsh prison sentences, expulsion from the state, loss of work and business [22].

Restrictions on freedom of expression of opinions or ideas are also carried out by instilling doctrine in journalism students. Students are taught that the government gives freedom to express ideas or opinions, but they must understand that informing people of something that can bring bad impacts to society is useless, even dangerous. Besides, the Chinese government also instills in journalists understanding that the interests of the government are the same as those of the people. "The party's newspapers are the people's newspaper." Therefore, people's thinking must be in line with the thoughts of the government. Furthermore, the press becomes a tool for government propaganda and the government is also checking the propaganda department in the Party Central Committee [22]. 
Freedom of speech in the press in China is not only done for local Chinese journalists. The influence of the Chinese government in controlling stability is huge, including deporting foreign journalists and prohibiting returning to China within a certain period of time. Even Hong Kong journalists must get permission from the Chinese government to do news coverage in China mainland [22].

Another effort to maintain the stability of the Chinese Government through the press is to establish censorship institutions. This institution is tasked to conduct a review of all information that is in, into, and out of China. The censorship agency also cooperates with the press to ensure that content displayed by the mass media contains government propaganda. The press agency is tasked with providing guidelines to the mass media for the limitations in content creation that will be published in the mass media, especially in the case of politically sensitive topics [23].

In the era of the development of telecommunications and information technology that has expanded rapidly, the Chinese government employs many civil servants to form a Great Firewall whose job is to censor content on the internet using bandwidth throttling methods, keyword filtering and blocking access to websites that are assessed not in line with the Chinese government propaganda, including Facebook, Twitter, Google, and Instagram. The Chinese government is blocking access to Facebook, Twitter, Google, and Instagram because the Chinese government cannot control the content on these sites and it is feared that the dissemination of information that is not following propaganda, such as democracy, can damage stability in China [23].

\section{2) Freedom of the Press in Norway}

Norway is a democratic country and based on press freedom ranking issued as in [18], Norway has been ranked first in the last three years in a row. The Norwegian government as in [24] believes that freedom of expression includes freedom to seek and receive information and express opinions that are prerequisites for participating in social and political life, so this is considered important as a basis for democracy.

Restrictions on freedom of opinion must be based on clear laws, for legitimate purposes, and democratic needs. In addition, freedom of opinion has limitations that need to be considered and monitored by the government, such as freedom that is misused to spread hatred and disturb other people or groups. So, besides giving freedom to its citizens to express opinions or ideas, the Norwegian government also pays attention to the limits not to interfere with other people's human rights. [24]

The Norwegian government provides freedom of the press and makes it an independent institution and supports pluralism in the media to support the creation of democracy. The media has a role as a government watchdog that has a fourth power in society and can carry out criticism and correction of abuse of power, corruption, and non-transparency. The state guarantees the confidentiality of sources and does not allow censorship. Norway also promotes press freedom and media independence, especially in conflicting, and undemocratic countries [24].

The seriousness of the Norwegian government in upholding press freedom in expressing its thoughts is not only seen by the absence of censorship and positioning the media as a government watchdog but also related to regulations that protect the performance of journalists. The number of incidents of violence against journalists, making the Norwegian government establish provisions to conduct investigations and give punishment to the perpetrators for every journalist killed will make more people are depressed in silence. The Norwegian government also provides support to UNESCO and media organizations in protecting journalists [24].

\section{Method}

This research was conducted by using a critical paradigm that saw a gap between existing regulations and the implementations in social reality. Besides, as a logical consequence of this paradigm then qualitative research methods were used so that the analysis results of data and observations were analyzed and perceived to explain the reality of the freedom of speech implementation in Indonesia [25]. 


\section{Results and Discussion}

The researcher conducted an analysis related to the press regulation of the 1999 Press Law and the Journalistic Code of Ethics. According to the articles in the 1999 Press Law [8], it can be seen that the Press Law only regulates crimes related to banning, censorship, and or broadcasting prohibition, reporting without respecting religion and decency, and the mass media agencies must take the form of Indonesian legal entities. This is under Article 18 of the 1999 Press Law, namely: (1) Everyone who, against the law, deliberately take action that caused hindrance or prevention of the criteria stated in Article 4 item (2) and item (3) will be sentenced to jail for 2 (two) years at the maximum or charged with fine of Rp. 500,000,000.- (five hundred million rupiahs) at the maximum; (2) Press company who violates the criteria as stated in Article 5 item (1) and item (2), and Article 13, will be charged with fine of Rp. 500,000,000.- (five hundred million rupiahs) at the maximum; (3) Press company who violates the criteria as stated in Article 9 item (2) and Article 12 will be charged with fine of Rp. 100,000,000.- (one hundred million rupiahs) [8].

Furthermore, the Journalistic Code of Ethics becomes a reference in the implementation of journalistic activities regulated in Article 7 paragraph (2) as in [8], "Journalist owns and adheres to The Ethic Codes of Journalistic." This is reinforced in Article 15 as in [8] concerning the function of the Press Council, namely, "Decide and control the compliance of the Code of Ethics of Journalistic." While the Journalistic Code of Ethics cannot be used as a source of law, because ethics is only a group of list about good and right attitudes in doing a job and does not contain legal consequences in it [26]. The Journalistic Code of Ethics only regulates journalistic activities in a professional manner.

This causes imbalance when there are problems related to the implementation of journalistic activities that are not following the Journalistic Code of Ethics, such as the process of finding information that is not balanced, not through adjustment or supporting strong and valid data, and containing false and slanderous news that can harm others materially and immaterially. Examples of the cases of Tommy Winata and Bambang Harimurti, where the Court has ruled that Bambang Harimurti is not subject to criminal penalties because this case is a Lex Specialist where the resolution of cases requires extraordinary procedures through the Press Council and Tommy Winata is given the right of reply to clarify the reporting in Tempo Magazine, even though the Tempo Magazine reporter has been found guilty of not being able to prove the truth of the news and containing Tommy's name without going through a confirmation process or procedural error. This Judge's decision was considered unfair for Tommy Winata since the right of reply could not replace the losses that had been suffered, such as a damaged reputation and threats to his employees [27].

The researcher finds that the existence of this case and several other cases related to defamation due to the absence of information seeking procedures that are following the Journalistic Code of Ethics, and the problem-solving that can be given only by the right to reply that the 'victim' cannot compensate for the loss, this proves the existence of inequality fulfillment of human rights as Indonesian citizens guaranteed in the 1945 Constitution. The 1945 Constitution has a higher legal status than the 1999 Press Law. In the 1945 Constitution Article 28 G as in [8] it states that "(1) the right to protection of his/herself, family, honor, dignity, and property, and shall have the right to feel secure against and receive protection from the threat of fear to do or not do something that is a human right; (2) the right to be free from torture or inhumane and degrading treatment."

This protection of human rights is also made clear in the Bill of Rights where freedom or right does not harm other rights or freedoms as in [28], "the enumeration in the Constitution of certain rights shall not be construed to deny or disparage others retained by the people." So when there are other people who have freedom that exceeds and injures the freedom of others, there needs to be a law that regulates the consequences fairly. Because social justice is guaranteed in the 1945 Constitution and Pancasila as the rights of all Indonesian citizens.

Inequality in the 1999 Press Law is very likely to occur since historically, the 1999 Press Law was made in a very short period of time, which is approximately two weeks due to pressure during the reform period. Also, the 1999 Press Law was made by journalists, from journalists, and for journalists. Supervision of the Journalistic Code of Ethics implementation is also carried out by the Press Council, which, although independent, is composed of its individuals. It is feared that this making and monitoring will only use one dominant perspective, namely the perspective of the press. Even though the press also involves the community in carrying out its professional work, 
there is a need to balance the Press Law regulations which can equalize the position of both sides [29].

The existence of regulations related to the 1999 Press Law indicates that the Indonesian government has made efforts to facilitate the presence of press freedom to reach a democratic country, and this is proven by Indonesia is ranked 124 out of 180 countries that implement freedom of speech in the world of the press as in [18], although it still needs to reinforce the freedom limitations so that ambiguity does not occur when applied. As a reference to the limitations of freedom of speech, it can refer to the implementation of the press law and the role of the government in the freedom of speech principle implementation in the State of Norway. The Norwegian government limits that freedom of expression must respect the rights of others, not uttering hate speech, or interfere with other people or groups of people.

The level of success for the implementation of the freedom of speech principle depends very much on the political system adopted by a country. The implementation of freedom of speech, especially in the press, will be easier to implement in a country that adopts a democratic political system. This will be different when freedom of speech is applied in a country that follows the Communist-Socialist political system since in that system the government has an enormous role in regulating the country, including the press.

China is an example of a country that has implemented a Communist-Socialist political system. The Chinese government will take firm action against journalists who write news about the collapse of the government. For example, the Chinese government jailed Tan Zuoren who reported the Chinese government's corruption related to the collapse of school buildings. This punishment does not only apply to people who work in the field of journalism, but also those who support the implementation of freedom of speech. Liu Xiaboo was jailed for eleven years for making a petition for reformation and freedom of speech in China, and this petition was signed by more than 2000 Chinese citizens. The Chinese government also banned the media from publishing news when Liu Xiaboo was awarded the Nobel Peace Prize [30].

The magnitude of the Chinese government's power over the press makes oversight of government performance uncontrollable by the people. The aim of the Communist-Socialist political system, where all assets are controlled by the state in the interests of the people, cannot be achieved. This is because with ownership of all assets by the state but in its management cannot be monitored by the people through the mass media, there may be a misuse of rights that will benefit those who have power alone. This will increase the gap between people who have power and ordinary people without power. Finally, the criticism that forms the basis of the CommunistSocialist political system, which is to eliminate the bourgeoisie, instead creates people who have power. The role of the mass media is only apparent because all press activities are only propaganda by people who have power.

\section{Conclusion}

The imbalance in the 1999 Press Law and the Code of Ethics of Journalism that become the basis of the professional journalists' work, considered only beneficial for the interests of the press without seeing the rights of other Indonesian citizens. For example, the case between Tommy Winata and Bambang Harimurti. Tempo parties get their freedom in obtaining and conveying information through its media, but in its implementation, it does not follow the principles of journalism and the Journalistic Code of Ethics. Violations of the Journalistic Code of Ethics occur in Article: (1) The Indonesian journalist is independent and produces news stories that are accurate, balanced and without malice; (2) The Indonesian journalist adheres to professional methods in the execution of journalistic duties; (3) The Indonesian journalist always verifies information, conducts balanced reporting, does not mix facts with biased opinion, and upholds the presumption of innocence principle [27].

In connection with the paragraph above, article 1 and 2 in the Journalistic Code of Ethics, explains that journalists must make the news without an agenda other than to provide accurate information by confirming the person whose name is included in the news. Article 3, journalists need to double-check data obtained with other supporting data, especially if the data obtained is weak. One example of weak data is using anonymous sources. 
Therefore, it is necessary to review the regulations, both the 1999 Press Law and the Journalistic Code of Ethics. The review can be done by involving several elements of the community that are considered to be related in the implementation of the professional journalists' work, to provide a variety of perspectives. After reviewing, any changes or rearrangement of regulations can be made. Then, there needs to be coordination between sectors in the legislative, executive, and judiciary related to the connection between the Press Law as a Lex Specialist with the Criminal Code, so there is no legal loophole that benefits one of the parties in trouble between the two law sources. Furthermore, by coordinating with the judiciary, it can be regulated how the limits of problem-solving in the implementation of the regulations before it is ratified.

With the effort to review and make changes to the Indonesian press regulations, it is hoped that the press roles as a supervisor of the government implementation as well as a forum for conveying ideas and information guaranteed in the 1945 Constitution can be well implemented.

\section{References}

[1] A. Taufik, B. Rurit, and C. Junaedy, "Ada Tomy di 'Tenabang'? - Nasional - majalah.tempo.co," Tетро, 2003. [Online]. Available: https://majalah.tempo.co/read/nasional/85648/ada-tomy-ditenabang?

[2] Nurul, "Wartawan Tempo Dituntut 2 Tahun," Detik, 2004. [Online]. Available: https://news.detik.com/berita/d-181415/wartawan-tempo-dituntut-2-tahun.

[3] "Mahasiswa Makassar tawuran, kampus dibakar | merdeka.com.".

[4] "Petisi - Dewan Pers Indonesia: Usut Pelanggaran Kode Etik Jurnalistik dalam Pemberitaan Tawuran Mahasiswa Makassar · Change.org." .

[5] "Identitas Tersebar, Pasien Corona Disebut Tertekan." .

[6] "Berita Bom Kuningan, Media Langgar Kode Etik.".

[7] Dewan Pers, "Dewan Pers," 2017. [Online]. Available: https://dewanpers.or.id/profil/lembaga.

[8] U. Pers, UU 40/1999 : pers. Indonesia, 1999, pp. 1-11.

[9] Satrio Saptohadi, "Pasang Surut Kemerdekaan Pers di Indonesia," J. Din. Huk., vol. 11, no. 1, pp. 123 $133,2011$.

[10] M. S. Dr. H. Mahi M. Hikmat, Jurnalistik: Literary Journalism. Kencana, 2018.

[11] I. Purwaningsih, "Dosen Pembimbing 1, 2 Dosen Pembimbing 2," vol. 2, pp. 1-9, 2012.

[12] “J.D.I.H. - Undang Undang Dasar 1945 - Dewan Perwakilan Rakyat.".

[13] V. P. Pickard G. Picard, "Essential Principles for Contemporary Media and Communications Policymaking," Oxford, 2017.

[14] P. M. Napoli, Foundation of Communications Policy, 2nd ed. New York: Hampton Press, 2003.

[15] B. Manan, Politik Publik Pers. Jakarta: Dewan Pers, 2012.

[16] Nacota Yeshida Sapahuma, "POLITIKA, Vol. 6, No.1, April 2015,” vol. 6, no. 1, 2015.

[17] "Beginilah sistem pers yang ada di luar negeri | merdeka.com.".

[18] "2019 World Press Freedom Index | RSF." .

[19] "Freedom of Expression in China: A Privilege, Not a Right | Congressional-Executive Commission on China.".

[20] "Jalan Tengah Demokrasi: antara Fundamentalisme dan Sekularisme - Tohir Bawazir - Google Buku.” .

[21] A. Knight, "Free speech in China," eJournalist, vol. 4, no. 2, 2004.

[22] S. Emmons, "Freedom of speech in China: a possibility or a prohibition," Loy. LA Int'l \& Comp. L. Rev., 2001. [Online]. Available: https://digitalcommons.lmu.edu/cgi/viewcontent.cgi?referer=https://www.google.com/\&httpsredir=1\&a rticle $=1523 \&$ context $=$ ilr. 
[23] Beina Xu, "Media Censorship in China," CFR. org, 2014. [Online]. Available: http://mercury.ethz.ch/serviceengine/Files/ISN/177388/ipublicationdocument_singledocument/c7c7448 d-b88c-422b-a89e-262aa269ffcf/en/p11515.pdf.

[24] J. T. Jensen, "International efforts to promote freedom of expression and independent media regjeringen.no," Head of Communications Trude Måseide, 2015. [Online]. Available: https://www.regjeringen.no/en/topics/foreign-affairs/human-rights/ny-struktur/norges-arbeid-forytringsfrihet-og-uavhengige-medier/id2358336/.

[25] A. Manzilati, U. B. Press, U. B. Media, and A. Suman, Metodologi Penelitian Kualitatif: Paradigma, Metode, dan Aplikasi. Universitas Brawijaya Press, 2017.

[26] S. O. G. K. P. A. A. S. F. S. H. dr. M. Jusuf Hanafiah, Etika kedokteran dan hukum kesehatan ed 4. Egc.

[27] "Kode Etik Jurnalistik - PDF Free Download." [Online]. Available: https://ocplayer.info/49060804Kode-etik-jurnalistik.html.

[28] L. Lessig, Fidelity \& Constraint: How the Supreme Court Has Read the American Constitution. Oxford University Press, 2019.

[29] Dewan Pers, "Dewan Pers," Dewan Pers, 2017. [Online]. Available: https://dewanpers.or.id/kontak/faq/start/10. [Accessed: 04-Apr-2020].

[30] "Media Censorship in China | Council on Foreign Relations." . 